\title{
NAMES IN ESTONIAN FOLK ASTRONOMY - FROM 'BIRD'S WAY' TO 'MILKY WAY'
}

\author{
Andres Kuperjanov
}

This article offers an overview of the different names for the Milky Way and the accompanying beliefs and myths, based on the material in the Estonian Folklore Archives.

Astronomically speaking, the Milky Way is a big stellar system - a galaxy. All stellar systems of similar type are called galaxies. Our sun is a fairly common star, lying at the outskirts of the Galaxy. The core of the Galaxy is located in the Sagittarius Constellation where the Milky Way is widest and brightest, but is unfortunately not visible at our latitude. The Galaxy is about $1 \mathrm{kpc}$ (kiloparsec) thick, $30-40 \mathrm{kpc}$ wide, and the Sun is $\sim 8.5 \mathrm{kpc}$ from the core.

\section{THE MILKY WAY IN ESTONIAN}

The word 'galaxy' comes from the Greek work gala 'milk'. According to Greek mythology, the Milky Way had formed from the milk of the goddess Hera. Researcher of Finnish folk belief Uno Harva maintains that such heavenly milk rivers exist also among Siberian peoples (Harva 1948). The Buryats used to have an interesting custom relating to the paths of birds and milk rivers - when an eagle flew over the yurta, a cup of milk or a drink of fermented milk was thrown into the air. In Estonia the common name for the Milky Way is the 'Bird Way' (Linnutee), but the name 'Milkpath' (Piimatee) has also been recorded in both western Estonia (H III 18, 415 (3) < Vigala parish) and eastern Estonia (H IV 8, 646 (27)< Palamuse parish), although the latter is most probably an influence from literature and the German background. The German heritage has probably also provided us with the name ‘Great Wagon' for Ursa Major.

Today the only generally accepted name for the Milky Way is Linnutee, though this used to vary by dialect and region. 'Bird Path'

http://www.folklore.ee/folklore/vol22/milkyway.pdf 


\section{Andres Kuperjanov}

(Linnurada) (ERA II 189, 79 (28) < Emmaste parish) was a name used in the islands, 'Stork Path' (Kuretee) (ERA II 18, 587 (6) < HarjuJaani parish) was probably not very widespread, occurring mainly in northwestern Estonia. But there are even more parallel names 'Heavenly Way' (Taevatee) (ERA II 62, 544/5 (12) < Kullamaa parish) and also 'Heavenly Street' (Taevatänav) (ERA II 69, 159 (51) < Noarootsi parish) were common in western Estonia. There are also records of 'Heavenly Row' (Taevarida) (AES < Risti parish), 'Heavenly Plant-Bed' (Taevapeenar) (ERA II 62, 159 (43-44)< Lääne-Nigula parish) and 'Winter Plant-Bed' (Talipeenar) (ERA II 60, 491 (105) < Martna parish). The name 'Heavenly Harbour' (Tähesadam) has been explained by the light it emits in a dark autumn night (AES < Kose parish).

In South-Estonian dialect, the name Linnutee has become transformed into Sirgutee (KKI, WS < Hargla parish - Aime Kuus (1947)) or Tsirgutii (AES < Setu county, Küllatuva village), but the meaning is the same.

\section{FOLK ASTRONOMY MATERIAL IN ESTONIA}

The different names for the Milky Way and other star names are a result of long-term collection work. Folk astronomy material is generally very scattered; material concerning the Milky Way is a pleasant exception to the rule. There are not many of these records, but the available material is relatively compact and offers a good general picture. The Milky Way must have been so generally well known that there was no additional need to determine its position, as is necessary with most other stars and constellations. The only other celestial phenomena documented are Pleiades and Orion. The rest of the records concerning folk astronomy are beyond any kind of criticism, they are few and are all alike. There were very good methodical instructions for collecting folk astronomy material (the last, e.g., by Prüller 1961), but the collectors clearly did not follow these in practice. It is also possible that researchers and collectors considered this a topic to be of little interest.

The text corpus of 9000 records was founded by German dictionary compilers and chroniclers. The earliest heavenly phenomena are found in 17th century dictionaries (Hiärne 1680) and chronicles 
(Russow 1920-1921). In addition to the star named 'Ox' (Härg), the name 'Wolf' (Hunt) is mentioned in S. H. Westring's Dictionary (Westring), and the Milky Way has been repeatedly referred to by Wiedemann $(1869,1876)$.

The oldest wide-ranging manuscript source on folk astronomy comes from Saaremaa Island and dates from 1817-1822. This is material collected by members of the Kuressaare Estonian Society on the initiative of J. W. Luce. However, the majority of folk astronomy records come from the period after Jakob Hurt turned to Estonians in 1888 with the proposition to start collecting our heritage and offered a questionnaire for that purpose (Hurt 1989). Cosmological principles had been explained in calendars since the beginning of the 18th century. The systematic collection of folk astronomy material was, however, to begin a hundred years later, at the end of the 19 th century. By that time, the clock and printed calendars had rendered practical folk astronomy extinct. Material on astronomy was actively collected again from 1927-1939. Since then, material reaching the archives has been of a more random nature.

Despite the good methodological instructions available, the results of the collection are far from glorious, even though J. Hurt's relatively good instructions were improved by P.-E. Prüller's specifications and extensive elaborations. It is obvious from the collected data that it was collected in an inappropriate manner: the collector knew little astronomy, the questioning took place during the daytime, and the narrator was probably not instructed to identify the objects more closely, which inevitably resulted in making the recorded material ambiguous. The quality of the material would have been immensely improved by the use of star maps as aid material as well as asking for connections with other constellations. The current material is characterised by lengthy answers from only a few informants, answers that are not echoed by other sources and an abundance of reports of low reliability. Since even commonly known knowledge was asked about and recorded in a non-uniform manner, the material cannot be analysed by statistical means. From earliest to latest, the sources mention a total of almost two hundred different constellation and planet names. 


\section{Andres Kuperjanov}

\section{BELIEFS CONCERNING THE MILKY WAY}

Motifs, beliefs and treatments found in folkloristic records are significantly improved by the interpretations of science historian and astronomer Heino Eelsalu. On the basis of runic songs and myths, he has attempted to calculate when the constellations were aligned in such a position that a myth of corresponding content could have emerged. Eelsalu started out with the presumption that constellations have a long life-time (the current classic constellations have undergone only minor changes in the past 4000 years) and that myths are re-narrated in basically unchanged form during periods of time that are quite considerable in the case of sacred texts. He has also attempted to interpret the Milky Way on several occasions. Concerning the Milky Way we find different myth relicts, everyday beliefs, customs and omens related to practical astronomy, but also explanations concerning the conception of the soul.

1. The Milky Way as a way of birds is a very widespread belief, and in Estonian archived material is most commonly noted as the road that migrant birds follow on their way to winter habitats and back.

Taeva tee - Linnu tee, mida mööda rändlinnud kevade ja sügisel käivad. Lindude juht on üks valge lind, luige sarnane, ilusa neiu peaga, mille ees keik kiskjad linnud värisevad. Kullid ja kotkad pugevad tema eest peitu pilverüngastesse. Tema elab suvel põhjakalju otsas, vaatab südaöö päikest ja teda toidetakse suurte lindude poolt põhjamaa magusate marjadega. Minu vanaema kolmas mees Jüri Nõmberg, kes oli vana meremees, nägi, kui üle suure mere juhtis see valge lind suurt karja linde maa poole. Ja lendas nii madalalt, et võis näha tema noore neitsi nägu ja laeva masti otsast pistis üks väsinud suur kull hirmuga tema eest lendu (ERA II 273, 266/7 (6) < Keila parish).

Heavenly Way - Bird Way that migrant birds travel in spring and autumn. The birds are led by a white bird, similar to a swan, with the head of a pretty maiden that all birds of prey fear. Hawks and eagles hide in the clouds from it. In the summer it lives on top of a boulder in the North, watches the midnight sun and is fed sweet northern berries by big birds. My grandmother's third husband, Jüri Nõmberg, was an old seaman and he saw how this white bird led a big herd of birds over the great sea towards 
land. It flew so low that its young maiden's face could be seen and a big tired hawk flew away from the ship's mast in fright.

In addition to Finno-Ugric peoples, the above belief is also well documented among Turkish-Altai peoples and some Slavic peoples. In most cases, the Bird Way was connected with geese, whereas the Germanic peoples even associated it with the traditional Martinmas goose (Lebeuf 1996: 150).

According to contemporary astronomy, there are two constellations in the Bird Way, two large birds - the Swan (Cygnus) and the Eagle (Aquila). The bird has been an important symbol in the religions of many nations. In our cosmogonic myth it is the creator of the world. If the cosmogonic myth were to be interpreted as astral folklore, one could state that the bird (it may possibly be a swan) that is most often found in Karelian rock art (Poikalainen \& Ernits 1998) has a nest in heaven and peppers the heaven with its eggs. Heino Eelsalu's calculations maintain that considering the precession, the North Pole used to be in the Swan Constellation 1419 and 40-45 thousand years ago. At those times, the bird was fixed in the sky for the whole night, just as if it were making its nest on the Bird Way (Eelsalu

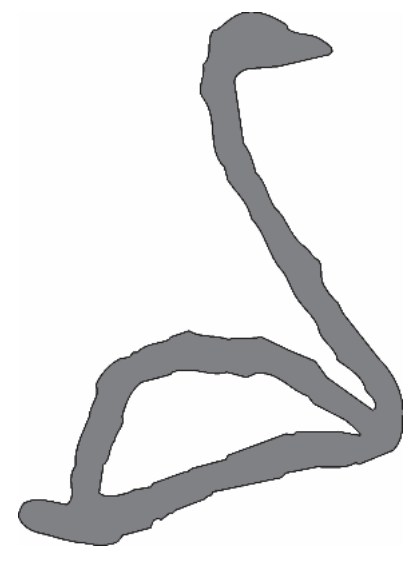

Figure 1. Swan from Karelian rock carving. By V. Poikalainen. 1985: 73).

2. The Milky Way as the road of the souls of the deceased is, once again, a motif found in the religion of many nations. The Milky Way has been mentioned as the road souls and the soul bird follow to the afterworld, Toonela. For Finno-Ugric peoples, the soul bird is a duck, diver or goose. Rock paintings from the White Sea imply that it could also be a swan or even the mythical bluebird / songbird / chirpbird (sinilind / midrilind, / sirjelind) referred to in runic songs (Peegel 1984). Also, St. Catherine's Day beggars come to heaven along a long road; they have been connected with the souls of the dead (Valk 1995). 


\section{Andres Kuperjanov}

The Milky Way has been described as the road of souls in the mythology of Antiquity, Old Germany (Lebeuf 1996: 150) as well as the North American indigenous peoples (Leach 1984: 726). The Milky Way is also reflected in different high religions - for the Tartars, it is the road to Mecca (Harva 1948), and in Christian interpretation the road Holy Mary took to heaven. Mary's trip along the Milky Way has been treated by Wiedemann as a belief common to Estonians. O. Loorits has also found that in folk heritage the Milky Way has been called the 'Way of Christ' (Kristuse tee in Estonian, Weg Christi in German), on which Kadri, a beautiful child, herded the heavenly people's herd.
Kadri oli kaunis lapsuke, istus Jeesukese tänaval,
Kadri was a beautiful child, kaitses püha Risti karja, taevaliste tallesida.
Sat in Jesus' street,
Protected the herd of the Holy Cross, (Karja parish; Loorits 1949) The eves of the heavenly people.

3. The Milky Way as traces, footprints is not a common explanation in Estonian heritage.

Seda halli riba taeva laotuses, mida rahvas Linnuteeks kutsub, olla vanapagan oma laia viiskudega kõndides tallanud, see olnud tema kõige suurem tee, kust tema alati oli käinud (H II 74, 801 (11) < Torma parish).
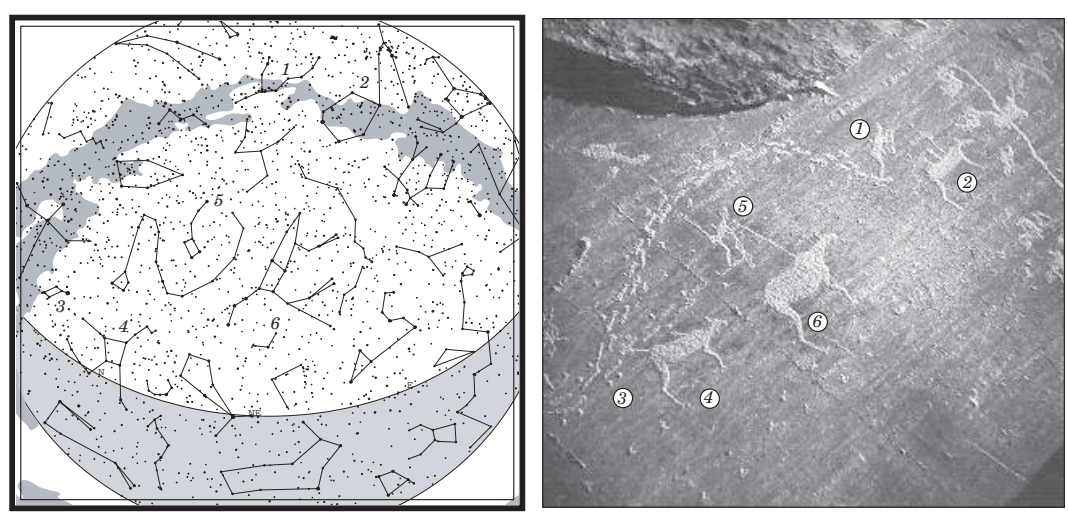

Figure 2. Milky Way as mythical hunt scene. Star map and rock carvings from North Karelia (River Vyg site). 
That grey strip in the sky that people call the Bird Way is where the old demon used to walk with his birch bark shoes, this was the widest road where he always walked.

The northern Finno-Ugric peoples know a myth about a hunt for the Sun Elk, with the Big Dipper or Ursa Major related to the elk and the Northern Star with the hunter in various interpretations. The Zalavruga rock art location in North Karelia features a group of hunting scenes that bears a resemblance to the starry sky. Let us attempt to follow this celestial hunt. The above picture holds the whole story of the hunt. The hunter (Perseus -1$)$ skis until he sees the first elk (Auriga - 2). His ski track is the Milky Way. The Milky Way is the sparsest in the Perseus - Auriga region - the tracks end at Perseus. Next the hunter (Vega-3) chases the elk (mainly Hercules -4), in the end he (the North Star, the skis are the back wheels of Ursa Minor - 5) secures the elk (Ursa Major - 6) with a lasso. The photo also shows lighter patches where the Pleiades and Taurus would be on the star chart.

4. The Milky Way as the world tree is characteristic not only of Finno-Ugric cosmology but that of almost all peoples. Many authors, including $\mathrm{H}$. Eelsalu, maintain that at the time when the North Pole was furthest from the Milky Way (in the Draco constellation), the Milky Way was fairly upright during the whole night and was thus reminiscent of a tree. Such a picture could be seen 5-9 and 31-35 thousand years ago

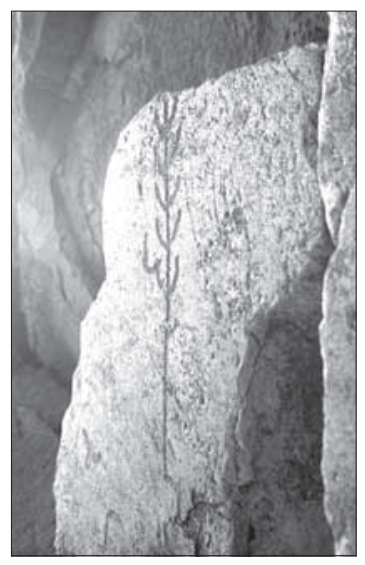

Figure 3. The World Tree from a Karelian rock carving. (Eelsalu 1985: 68).

The original 'World Tree' was a fig tree, in biblical areas a cedar in Lebanon, among the Germanic people an ash, in the Balto-Finnic area an oak, and further beyond, a birch.

The World Tree is a model of the world. It is often depicted as a giant tree with its branches covered with stars, on its top stands a bird and a snake on the roots. Thus is the world tree Yggdrasill depicted in ancient Scandinavian religion, for example. In contem- 


\section{Andres Kuperjanov}

porary astronomy there is indeed a snake in the Milky Way, in addition to the birds - in the constellation Serpens Cauda - Tail of the Snake. The Snake is borne by the nearby Ophiuchus constellation.

As the North pole shifted, the Milky Way began to lean. This is a possible source for the stories and songs of the cutting of the world tree. Aado Lintrop points out that we find two different descriptions of the world tree or Great Oak in Estonian runic songs (Lintrop 1999). The first is the classical world tree: an ancient oak, similar to Yggdrasil, with a bird at the top and stars on the branches, etc. This tree is a symbol of durability and consistency. The other Great Oak resembles the Huluppu-tree of Gilgamesh. We find descriptions of this oak in the runic songs 'Drowned Brother' (Uppunud veli) and 'Ship tree' (Laevapuu). This Huluppu-oak also has some features in common with the world tree - bird nests in the treetop, a snake lives in its roots. But it was planted by man, it shades light and confuses the movement of the clouds. To an extent, it is the opposite of the world tree. Household gadgets are made out of the wood from this oak. But the real world tree still stands.

5. The Milky Way and the winter peak. In the old timekeeping system, the Milky Way was primarily a sign of the end and beginning of the year. In the Estonian folk calendar the Winter Peak Day (Feb. 12) should fall on the date when winter has reached its peak and is retreating - the weather starts to become warmer and the arrival of spring approaches. According to K. Vilkuna, the name also referred to the fact that the Milky Way was at its highest point at about the same time (Vilkuna 1960). H. Eelsalu has estimated that about 3000 years ago this coincided with the winter solstice (Eelsalu 1985: 62). Today the peak of winter has shifted, due to the precession of the spring point to the end of January or beginning of February (in the calendar, dated as January 14, while Hupel and Wiedemann, for example, have erroneously dated it to March 12). The winter peak used to be an important marker in the old calendar system, a sign by which the lunar calendar could be synchronised with the real year.

It is not unnecessary to reiterate that the motif of cutting down the world tree has often been connected with the winter peak. 
6 . There are a number of myth relics connected with the Milky Way that are not found in Estonia. Many peoples have associated the Milky Way with a river, bridge or boundary between worlds. Perhaps these are hidden in the oldest of the runic songs, but so far they have not been found. It is also possible that such motifs can be found in the songs of St. Catherine's Day.

7. Indian and American peoples have connected the Milky Way with The Gates of Heaven. The concept of a gate on the heavenly road is known also among other nations. The Gates of Heaven are usually connected with two bright red stars near the Milky Way - Antares and Aldebaran (Lebeuf 1996: 152). Both stars are visible here, though Antares is fairly low. The constellations of Taurus and Scorpius marked the equinox approximately 5500 and the solstice 15000 years ago. According to Plato, the Gates of Heaven are Cancer (sc. Gate of Humans that the soul passes to enter the human body) and the Capricornus (or the Gate of Gods that the soul passes on its way back to heaven) that are some distance from the Milky Way (Jaaniste \& Saar 1990: 114, 178). In Plato's lifetime, the solstice-marking constellations had instead become Gemini and Sagittarius. There is reason to believe that the gates were rather connected with the points on the ecliptic determining the changing of the seasons, and the connection with the Milky Way is a relict.

In Estonia, too, there is a belief in a Christian background concerning the gates of heaven. According to this belief, the souls had to pass the gates of heaven to reach paradise. Unfortunately, there is no definite connection between the gates of heaven and a fixed star or group of stars, even though the folklorist M. J. Eisen states: "One group of stars carry the name Gates of Paradise" (Eisen 1919). Some ambiguous folk astronomy records lead me to presume it might have been the constellation of the Northern Crown (Corona Borealis).

\section{PRACTICAL USES OF THE MILKY WAY}

The Milky Way also had a practical purpose. As mentioned before, it leads birds on their way to warmer lands - a belief held by many peoples. But it also helps humans orient: 


\section{Andres Kuperjanov}

Kui sa ära eksid, siis jälle üks märk, et vaata Linnuteed, et siis sa ei eksi ära (ERA II 77, 84 (5) < Jüri parish).

When you get lost, then another sign is to look at the Milky Way, then you won't get lost.

The Milky Way used to be not only a calendar mark but also a clock:

Kus Linnutee ja Rattad taevas - selle järele vaadati kella vanasti, (vanasti ei olnud seinakellasid), et teada, millal metsa minna (ERA II 302, $212(124)<$ Valjala parish).

Where the Milky way and Wheels were in the sky - that was the time-teller in old times (in old times there were no wall clock) to know when to go to the forest.

The Milky Way has been used for both short-term and long-term weather prognosis:

Linnuteest tunneb seda ära, kas hää ilm tuleb või paha ilm: kui ta segane ja pime on, siis tuleb paha ilm, kui jälle selge ja kõrgest läbi käib, siis on ilmad hääd (H III (4) < Karja parish).

The Milky Way shows whether there will be good weather or bad weather: if it is blurred and dark, there will be bad weather, but if it is clear and high in the sky, then the weather will be good.

Sügisel ennustatakse Taevatänavast ehk Taevateest talve tulekut. Kui taevatänav on kord üle valge, siis tuleb talve üsna suur ja sügav, st lumerohke. On aga Taevatänav mustalaiguline, siis ennustatakse, et need mustad laigud on selle talve sulad - seega sularohke talv. Kui Taevatänav juhtub olema eest (kirde või põhja) otsast tume, keskkohalt selge ja tagant (edela) otsast samuti tume, siis tuleb talve jõulut ja kevade poole sularohke, kesktalve aga lumerohke. Ehk kui Taevatänav on keskelt tume, otste pealt valge, siis enne jõulu ja kevade poole lumerohke ja kesk talve sularohke. Kui Taevatänav on üldse tume, tuleb kehv talv ehk madal talv (ERA II 69, 159 (51) < Noarootsi parish).

In the autumn the Heavenly Street or Heavenly Way is used to predict the arrival of winter. If the heavenly street is once white all over, the winter will be quite long and deep, i.e. rich in snow. But if the heavenly street is spotted with black, these black spots 
are said to be thaws in the winter - there will be many thaws. If the heavenly street happens to be dark in the front (northeastern or northern) part, clear in the middle and also dark in the back (southwestern) part, there will be thaws before Christmas and towards spring, but there will be a lot of snow in the midwinter. Or, if the heavenly street is dark in the middle and white near its ends, there will be much snow before Christmas and towards spring, and many thaws in the midwinter. If the heavenly street is dark all over, there will be a poor winter, i.e. with a low level of snow.

As the above example demonstrates, people used to study the structure of the Milky Way with great interest. The branching of the Milky Way, called 'Kadri's Fork' (Kadrihark), has been described in a record from Lääne-Nigula:

Üks Hiiumaa mees küsis vabrikuhärra vahimehe käest: "Kas saab jõuluks saanisõitu? Kas tuleb lund?” Vanamees haigutas, vaatas üles Taevapeenart. See põle hästi valge, Kadrihark old must. See on kaheharaline, sügiseaegu paistab. Kui see peab väga valge olema, siis on pailu lund (ERA II 62, 159 (44) < Lääne-Nigula parish).

A man from Hiiumaa Island asked the factory owner's guard: Will there be sledge-riding by Christmas? Will there be a lot of snow? The old man yawned, looked up the Heavenly Plant-Bed. This shone very brightly, and the Kadri's Fork was black. It has two branches, seen around autumn. If it is very white, there will be a lot of snow.

Observation of the Milky Way most likely does no allow for longterm forecasts, but it may provide reliable results about the weather of the next day. If there are high cirrus clouds approaching from the west, the stars shine, but the Milky Way is dark. This picture means that there is a storm, rain, etc. coming.

\section{SUMMARY}

The belief system connected with the Milky Way may have been much more abundant than is reflected by archived texts, since the work of systematic collection only began once the material had prac- 


\section{Andres Kuperjanov}

tically perished. There are only traces of old myths, relics and barely connectable fragments of runic songs. Nevertheless, there are signs of the old world system to be found in them: the gathering of souls on heavenly paths and the connections stars have with the birth and death of people. Usually we obtain information on the level of everyday beliefs - mainly about the weather and omens concerning success.

\section{Abbreviations}

AES - folklore collection of the Academical Association of Mothertongue in the Estonian Folklore Archives.

$\mathrm{H}$ - the Hurt manuscript collection in the Estonian Folklore Archives, 1860-1906.

ERA - Estonian Folklore Archives.

\section{References}

Eelsalu, Heino 1985. Ajastult ajastule [From Era to Era]. Tallinn: Valgus.

Eisen, Matthias Johann 1919. Eesti mütoloogia [Estonian Mythology]. Tallinn: Eestimaa Kooliõpetajate Vastastiku Abiandmise Seltsi raamatukauplus.

Harva, Uno 1948. Suomalaisten muinaisusko [Finnish Ancient Religion]. Porvoo \& Helsinki: Söderström

Hiärn[e], Thomas 1932. Kuu teretus. Gustav Suits \& Mart Lepik (ed.). Eesti kirjandusajalugu tekstides [Estonian Literary History in Texts], 1. Akadeemilise Kirjandusühingu Toimetised, 4. Tartu: Akadeemiline Kirjandusühing, pp. 126. (Source: T. Hiärn. Ehst-, Lyv- und Lettländische Geschichte 1. Miitav 1794.)

Hurt, Jakob 1989. Eesti astronomia. Kõne Eesti Jaani koguduse Noortemeeste Seltsis 10. Jaanuaril 1899. Jakob Hurt. Mida rahvamälestustest pidada:Artiklite kogumik [How to Regard Folklore: A Collection of Articles]. Tallinn: Eesti Raamat, pp. 91-130.

Jaaniste, Jaak \& Saar, Enn 1990. Täheatlas: Käsiraamat [Star Atlas: A Handbook]. Tallinn: Valgus.

Leach, Maria 1972. Funk \& Wagnalls Standard Dictionary of Folklore, Mythology and Legend. New York: Funk \& Wagnalls.

Lebeuf, Arnold 1996. Milky Way a Path of the Souls. Vesselina Koleva \& Dimiter Kolev (eds.). Astronomical Traditions in Past Cultures: Proceedings 
of the SEAC 1993 Meeting in Bulgaria. Sofia: Institute of Astronomy \& Academy of Sciences, pp. 148-161.

Lintrop, Aado 2000. Suur tamm ja õde-venda. Mäetagused: Hüperajakiri, 13, Tartu: Eesti Kirjandusmuuseum, pp. 24-42 (http:// haldjas.folklore.ee/tagused/nr13/).

Loorits, Oskar 1949. Grundzüge des estnischen Volksglaubens, 1. Skrifter Utgivna av Kungl. Gustav Adolfs Akademien för Folklivsforskning, 18: 1. Lund: Carl Blom.

Peegel, Juhan 1984. Nimisõna poeetilised sünonüümid eesti regivärssides [Poetical Synonyms for Nouns in Estonian Runic Songs], 2. Eesti NSV Teaduste Akadeemia Emakeele Seltsi toimetised, 15. Tallinn: Eesti Raamat.

Poikalainen, Väino \& Ernits, Enn 1998. Rock Carvings of Lake Onega: Vodla Region. Tartu: Estonian Society of Prehistoric Art.

Prüller, Paul-Egon 1961. Juhend täiendavate andmete kogumiseks eesti rahvaastronoomia alalt. Rahvapärimuste koguja: kirjandusmuuseumi kogumistöö juhendaja [Collector of Folklore], 2. Tartu: Fr.R.Kreutzwaldi nim. Kirjandusmuuseum, pp. 51-71.

Russow, Balthasar 1920-1921. Liivimaa kroonika [The Livonian Chronicle], I-II. Eesti Kirjanduse Seltsi Ajalootoimkonna toimetused 1a1b. Tartu: Eesti Kirjanduse Selts.

Valk, Ülo 1995. Eesti mardilaulude usundilisest taustast. Hiiemäe, Mall \& Kõiva, Mare (eds.). Rahvausund tänapäeval [Folk Belief Today]. Tartu: Eesti TA Eesti Keele Instituut \& Eesti Kirjandusmuuseum, pp. 471-478.

Westring, Salomo Heinrich. Lexicon Esthonico Germanicum (http:// haldjas.folklore.ee/ kriku/VESTRING/index.htm).

Wiedemann, Friedrich Johann 1869 (1893). Ehstnisch-Deutsches Wörterbuch. Sankt-Peterburg: Kaiserliche Akademie der Wissenschaften.

Wiedemann, Friedrich Johann 1876. Aus dem inneren und äusseren Leben der Ehsten: Der Akademie vorgelegt am 30. Sept. 1875. Sankt-Peterburg: Kaiserliche Akademie der Wissenschaften.

Vilkuna Kustaa 1960. Vuoden neljännekset ja viikkolasku. Kalevalaseuran Vuosikirja, 40. Helsinki: Suomalaisen Kirjallisuuden Seura. 